(c) American Dairy Science Association, 2004.

\title{
Effect of Supplemental L-Lysine-HCL and Corn Source on Rumen Fermentation and Amino Acid Flow to the Small Intestine
}

\author{
J. K. Bernard, ${ }^{1}$ P. T. Chandler, ${ }^{2}$ J. W. West, ${ }^{1}$ A. H. Parks, ${ }^{3}$ H. A. Amos, ${ }^{3}$ \\ M. A. Froetschel, ${ }^{4}$ and D. S. Trammell ${ }^{1}$ \\ ${ }^{1}$ Department of Animal and Dairy Science, \\ The University of Georgia, Tifton 31793-0748 \\ ${ }^{2}$ Chandler \& Associates, Dresden, TN 38225 \\ ${ }^{3}$ College of Veterinary Medicine, Department of Large Animal Medicine, \\ The University of Georgia, Athens 30602-7385 \\ ${ }^{4}$ Department of Animal and Dairy Science, \\ The University of Georgia, Athens 30602-2771
}

\begin{abstract}
Four lactating Jersey cows fitted with ruminal and duodenal cannulae were used in a $4 \times 4$ Latin square design trial to determine the effect of supplemental lysine in diets containing dry ground (GC) or steamflaked (SFC, $360 \mathrm{~g} / \mathrm{L}$ ) corn on ruminal fermentation and amino acid (AA) flow to the duodenum. Supplemental L-lysine-HCL provided $10 \mathrm{~g} / \mathrm{d}$ of additional Lys to the total mixed rations. There were no interactions between supplemental Lys and corn source. Supplemental Lys increased Lys intake, but did not alter nutrient intake and digestibility or $\mathrm{N}$ flow to the duodenum. Intake of dry matter (DM), organic matter (OM), and neutral detergent fiber (NDF) and ruminal digestibility of starch tended to be higher, whereas ruminal digestibility of DM, OM, acid detergent fiber, and NDF was lower for diets supplemented with SFC compared with GC. Whole-tract digestibility was similar for both corn supplements. Ruminal $\mathrm{pH}$ and molar proportions of volatile fatty acids were not affected by supplemental Lys or corn source; however, ruminal $\mathrm{NH}_{3}$ concentrations were lowest when SFC was fed. Intake of $\mathrm{N}$ tended to be higher and the flow of total $\mathrm{N}$ and individual $\mathrm{AA}$ to the duodenum was higher for diets supplemented with SFC. There was a trend for increased flow of microbial $\mathrm{N}$ for diets supplemented with SFC. Supplemental Llysine-HCL did not alter ruminal fermentation, flow of amino acid to the small intestine, or nutrient digestibility, but feeding SFC reduced ruminal fiber digestion and increased microbial protein synthesis and flow of amino acid to the duodenum.
\end{abstract}

(Key words: amino acid, steam-flaked corn, digestibility, supplemental lysine)

Received: May 9, 2003

Accepted: July 19, 2003.

Corresponding Author: J. K. Bernard; e-mail: jbernard@tifton. cpes.peachnet.edu.
Abbreviation key: $\mathbf{G C}=$ ground corn, $\mathbf{S F C}=$ steamflaked corn.

\section{INTRODUCTION}

One of the goals of protein nutrition for dairy cattle outlined by NRC (2001) is to provide adequate amounts of RDP to optimize microbial protein synthesis and provide additional RUP needed to optimize the quantity of absorbable AA flowing to the small intestine. Carbohydrate digestion is one of the major factors influencing energy availability in support of microbial protein synthesis (Hoover and Stokes, 1991). Improvements in carbohydrate digestion can be achieved by processing grain so that more starch is fermented in the rumen. Steamflaking corn (SFC) has been shown to increase ruminal starch digestibility and flow of microbial protein to the small intestine (Theurer et al., 1999). However, decreasing the particle size of corn by grinding or steamflaking has resulted in decreased ruminal NDF digestibility and increased postruminal NDF digestibility (Joy et al., 1997; Callison et al. 2001).

Lysine is typically considered the most limiting or colimiting AA for milk production (Schwab et al., 1992a, 1992b). Limited data are available describing the effects of supplementing L-lysine-HCL in lactating dairy cows. Previous research indicated that only 5\% of the supplemental Lys from L-lysine-HCL escaped ruminal digestion (Amos and Evans, 1978). However, a recent report suggest that up to $18.6 \%$ of the Lys provided by L-lysine-HCL escapes ruminal degradation $8 \mathrm{~h}$ after intraruminal administration (Velle et al., 1998). If a greater proportion of L-lysine-HCL escaped ruminal degradation, it could possibly be used to economically increase the supply of Lys postruminally in support of milk synthesis. Harrison et al. (2000, personal communication) recently reported increased milk yield and fat percentage when L-lysine-HCL and protected Met were fed during early lactation. These researchers also ob- 
served a numeric increase in concentrations of milk allantoin, suggesting that these AA supplements may have stimulated microbial protein synthesis.

The objectives of this study were to determine the effect of supplemental L-lysine-HCL in diets containing either ground corn (GC) or SFC on ruminal fermentation, fiber digestion, and flow of dietary and microbial $\mathrm{N}$ to the small intestine.

\section{MATERIALS AND METHODS}

Four lactating Jersey cows $(81.8 \pm 7.6$ DIM $)$ previously fitted with ruminal and duodenal gutter cannulae were used in a $4 \times 4$ Latin square with a $2 \times 2$ factorial arrangement of treatments to provide 2 levels of supplemental L-lysine-HCL ( 0 or + ) and 2 sources of corn (GC or SFC). The supplemental Lys (Biolys 60, Degussa Corporation, Parsippany, NJ) was added to Prolak (H. J. Baker \& Bros., Inc., Stamford, CT ) and fed at a rate to provide $10 \mathrm{~g} / \mathrm{d}$ of supplemental Lys. The amount of supplemental Lys was based on the degradability estimates of Velle et al. (1998), and the results of the CPM model analyses (O'Connor et al., 1993). The SFC was prepared at a local mill to a density of $360 \mathrm{~g} /$ L (South Georgia Grain Services, Albany, GA). Cows were cannulated and managed according to procedures approved by the University of Georgia Institutional Animal Care and Use Committee. Experimental periods were $14 \mathrm{~d}$ in length with $\mathrm{d} 1$ through 9 for ration adjustment and $d 10$ through 14 for sample collection. Composition of experimental diets is given in Table 1. Two concentrates were mixed containing either GC or SFC, whole cottonseed, soybean meal, Megalac (Church \& Dwight Co., Inc. Princeton, NJ), urea, dicalcium phosphate, and a trace mineral-vitamin premix. Chromic oxide was included in each concentrate mix to provide approximately $20 \mathrm{~g} / \mathrm{d}$ per cow as an inert marker for determining digesta flow to the duodenum and calculation of apparent digestibility of nutrients. Diet ingredients were mixed to form a TMR and fed once daily behind Calan gates (American Calan Inc., Northwood, $\mathrm{NH}$ ) in amounts to ensure $10 \%$ refusal. The amount of TMR offered and refused were recorded daily. Samples of ingredients and TMR were collected on d 10 through 14 and composited for each experimental period.

Duodenal and fecal samples were collected on d 10 , 11,12 , and 13 at 12 -h intervals. The sampling schedule was advanced by $1 \mathrm{~h}$ each day. Equal amounts of samples were composited by cow within each period. Duodenal samples were lyophilized to dryness and fecal samples were dried in a forced air oven at $55^{\circ} \mathrm{C}$ for approximately $72 \mathrm{~h}$.

Ruminal fluid was collected at $0,2,4,6$, and $8 \mathrm{~h}$ after the a.m. feeding from each cow for analyses of $\mathrm{pH}$, ammonia, and VFA on d 14. Samples were acidified with metaphosphoric acid and frozen for VFA analysis (Supelco, Bellefonte, PA). Sample $\mathrm{pH}$ and ammonia concentrations were determined using specific ion electrodes (Orion Research Inc., Boston, MA). An additional $200 \mathrm{~mL}$ of ruminal fluid was collected at each sampling time and composited. Bacteria were isolated from ruminal fluid composite samples by treatment using a KSB continuous flow system (Kendro Laboratory Products, Newtown, CT) and lyophilized to dryness.

Whole blood samples were collected $4 \mathrm{~h}$ postfeeding on $\mathrm{d} 14$ by jugular venipuncture. Tubes were allowed to clot and serum was harvested by centrifugation. Concentrations of urea N using a Boehringer Mannheim/ Hitachi 912 automated chemistry analyzer (Roche Diagnostics, Indianapolis, IN). Glucose concentrations were measured by the glucose hexokinase method using a Boehringer Mannheim/Hitachi 912 automated chemistry analyzer (Roche Diagnostics).

Ingredient, duodenal, and fecal samples were ground to pass through a 1-mm screen using a Wiley mill (Arthur H. Thomas, Philadelphia, PA). Samples were analyzed for concentrations of DM, ash (AOAC, 1990), total N (FP-528, Protein/Nitrogen Analyzer, Leco Corporation, St. Joseph, MI), NDF, ADF (Van Soest et al., 1991), and starch (Hall, 2001). Concentrate, duodenal, and fecal samples were analyzed for chromic oxide content by colorimetry (Brisson, 1956; model DU-64; Beckman Instruments, Inc., Fullerton, CA). Amino acid concentrations in ingredient, duodenal, and bacterial isolate samples were determined according to AOAC (2002). Purine concentration in duodenal and bacterial isolates were determined according to Zinn and Owens (1986) to differentiate between dietary and microbial AA reaching the small intestine.

Data were subjected to ANOVA using PROC GLM procedures of SAS (1989). The model included effects due to cow, period, Lys supplementation, corn source, and the interaction of Lys supplementation and corn source. PROC MIXED procedures of SAS (1989) were used to analyze ruminal VFA, ammonia, and $\mathrm{pH}$ data to account for the multiple sampling within each period. Data from 1 cow during periods 3 and 4 were omitted because of problems unrelated to experimental treatments.

\section{RESULTS AND DISCUSSION}

The calculated nutrient composition of the experimental diets (based on nutrient content of ingredients) is presented in Table 1, and the chemical composition of dietary ingredients used in the experimental diets is presented in Table 2. Nutrient content of ingredients and experimental diets was within expected ranges. 
Table 1. Ingredient and chemical composition of experimental diets.

\begin{tabular}{|c|c|c|c|c|}
\hline \multirow[b]{2}{*}{ Corn source } & \multicolumn{2}{|c|}{ No supplemental lysine } & \multicolumn{2}{|c|}{ Supplemental lysine } \\
\hline & Ground & Steam flaked & Ground & Steam flaked \\
\hline \multicolumn{5}{|l|}{ Ingredients } \\
\hline Alfalfa hay & 30.40 & 30.40 & 30.40 & 30.40 \\
\hline Corn silage & 19.95 & 19.95 & 19.95 & 19.95 \\
\hline Prolak $^{1}$ & 3.26 & 3.26 & & \\
\hline Prolak + lysine ${ }^{2}$ & & & 3.26 & 3.26 \\
\hline Ground corn ${ }^{3}$ & 27.70 & & 27.70 & \\
\hline Steam flaked corn ${ }^{3}$ & & 27.70 & & 27.70 \\
\hline Cottonseed $^{3}$ & 11.10 & 11.10 & 11.10 & 11.10 \\
\hline Soybean meal, $48 \% \mathrm{CP}^{3}$ & 3.38 & 3.38 & 3.38 & 3.38 \\
\hline Urea $^{3}$ & 0.36 & 0.36 & 0.36 & 0.36 \\
\hline Megalac $^{3}$ & 1.81 & 1.81 & 1.81 & 1.81 \\
\hline Dicalcium phosphate $^{3}$ & 0.36 & 0.36 & 0.36 & 0.36 \\
\hline Premix & 1.69 & 1.69 & 1.69 & 1.69 \\
\hline \multicolumn{5}{|l|}{ Chemical } \\
\hline Ash & 8.17 & 7.93 & 8.16 & 7.92 \\
\hline $\mathrm{CP}$ & 15.91 & 15.87 & 15.91 & 15.88 \\
\hline RUP $^{5}$ & 6.75 & 6.75 & 6.75 & 6.75 \\
\hline $\mathrm{ADF}$ & 18.06 & 17.78 & 18.01 & 17.73 \\
\hline $\mathrm{NDF}$ & 28.20 & 28.53 & 28.12 & 28.46 \\
\hline Starch & 22.57 & 20.78 & 22.58 & 20.80 \\
\hline $\mathrm{NE}_{1}^{5}$ & 1.74 & 1.76 & 1.74 & 1.76 \\
\hline
\end{tabular}

${ }^{1}$ H. J. Baker \& Bros., Inc., Stamford, CT .

${ }^{2}$ Supplemental L-lysine-HCL was provided by Biolys 60, Degussa Corporation, Parsippany, NJ.

${ }^{3}$ Ingredients were mixed to form a concentrate.

${ }^{4}$ Premix contained (DM basis) $1.11 \%$ of $\mathrm{Ca} ; 5.14 \%$ of $\mathrm{Mg} ; 17.73 \%$ of $\mathrm{K}, 12.77 \%$ of $\mathrm{Na} ; 7.58 \%$ of $\mathrm{Cl} ; 1.93 \%$ of S; $20 \mathrm{ppm}$ of Co; $700 \mathrm{ppm}$ of Cu; $225 \mathrm{ppm}$ of Fe; $69 \mathrm{ppm}$ of I; $2116 \mathrm{ppm}$ of Mn; $16 \mathrm{ppm}$ of Se; 2,079 ppm of Zn; $141,000 \mathrm{IU} / \mathrm{kg}$ of vitamin A; 56,000 IU/kg of vitamin D; and $699 \mathrm{IU} / \mathrm{kg}$ of vitamin $\mathrm{E}$.

${ }^{5}$ Calculated using NRC (1989) values.

There were no interactions $(P>0.10)$ of supplemental Lys and corn source observed for any variable; therefore, main effect means are presented. Average DMI during the trial was $15.3 \mathrm{~kg} / \mathrm{d}$ or $3.3 \%$ of BW and average milk yield was $23.5 \mathrm{~kg} / \mathrm{d}$ and milk contained $4.09 \%$ fat and $2.89 \%$ protein. Intake and apparent digestibility of nutrients in the reticulo-rumen and whole tract were not affected by the addition of supplemental Lys to the diets (Table 3). Intake of DM, OM, and NDF tended ( $P$ $<0.07)$ to be higher for diets containing SFC compared with GC. Ruminal apparent digestibility of DM $(P<$ $0.02)$, OM $(P<0.05)$, and NDF $(P<0.01)$ was lower, and ADF tended to be higher $(P<0.10)$, but apparent digestibility of starch tended to be higher $(P<0.10)$ for diets supplemented with SFC compared with GC. However, whole tract apparent digestibility of nutrients was similar for both GC and SFC indicating greater fiber digestion postruminally for diets supplemented with SFC.

There were no interactions observed between treatments and time of sampling for ruminal metabolites. Ruminal $\mathrm{pH}$, concentrations of $\mathrm{NH}_{3}$ and total VFA, and molar proportions of individual VFA were similar for diets with and without supplemental Lys (Table 4).

Table 2. Chemical composition of ingredients used in experimental diets.

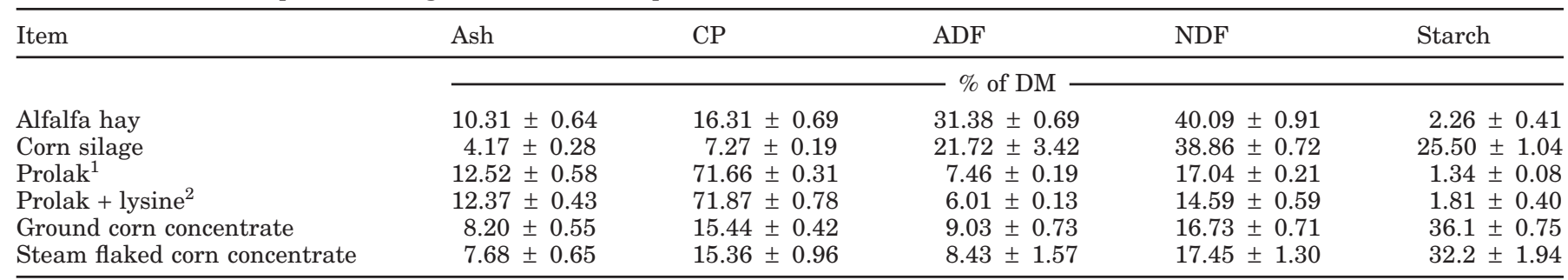

${ }^{1}$ H. J. Baker \& Bros., Inc., Stamford, CT.

${ }^{2}$ Supplemental L-lysine-HCL was provided by Biolys 60, Degussa Corp., Parsippany, NJ. 
Table 3. Nutrient intake and apparent digestibility for lactating cows consuming diets containing supplemental lysine and processed corn.

\begin{tabular}{|c|c|c|c|c|c|c|c|c|}
\hline & \multicolumn{3}{|c|}{ Lysine supplementation } & \multirow[b]{2}{*}{$\mathrm{P}$} & \multicolumn{3}{|c|}{ Corn processing } & \multirow[b]{2}{*}{$\mathrm{P}$} \\
\hline & 0 & + & $\mathrm{SE}$ & & $\mathrm{GC}^{1}$ & $\mathrm{SFC}$ & $\mathrm{SE}$ & \\
\hline \multicolumn{9}{|c|}{ Intake, kg/d } \\
\hline DM & 15.3 & 15.4 & 0.3 & $\mathrm{NS}^{2}$ & 14.9 & 15.8 & 0.3 & 0.07 \\
\hline $\mathrm{OM}$ & 14.1 & 14.2 & 0.3 & NS & 13.7 & 14.5 & 0.3 & 0.07 \\
\hline $\mathrm{ADF}$ & 2.6 & 2.6 & 0.1 & NS & 2.5 & 2.7 & 0.1 & NS \\
\hline NDF & 4.0 & 4.1 & 0.1 & NS & 3.9 & 4.2 & 0.1 & 0.07 \\
\hline Starch & 3.1 & 3.3 & 0.2 & NS & 3.3 & 3.1 & 0.2 & NS \\
\hline \multicolumn{9}{|c|}{ Reticulo-rumen apparent digestibility, \% } \\
\hline $\mathrm{DM}$ & 47.5 & 48.0 & 2.8 & NS & 54.7 & 40.9 & 2.8 & 0.02 \\
\hline $\mathrm{OM}$ & 54.7 & 56.8 & 1.9 & NS & 59.2 & 52.2 & 1.9 & 0.05 \\
\hline $\mathrm{ADF}$ & 44.6 & 41.8 & 4.6 & NS & 51.1 & 35.3 & 4.9 & 0.10 \\
\hline NDF & 45.8 & 49.0 & 1.8 & NS & 56.1 & 38.7 & 1.9 & 0.01 \\
\hline Starch & 68.0 & 64.7 & 4.8 & NS & 65.2 & 67.4 & 5.0 & 0.10 \\
\hline \multicolumn{9}{|c|}{ Whole tract apparent digestibility, \% } \\
\hline DM & 73.5 & 74.8 & 1.3 & NS & 73.5 & 74.7 & 1.3 & NS \\
\hline $\mathrm{OM}$ & 75.5 & 76.5 & 1.4 & NS & 75.0 & 76.9 & 1.3 & NS \\
\hline $\mathrm{ADF}$ & 49.0 & 51.9 & 2.3 & NS & 53.3 & 47.6 & 2.3 & NS \\
\hline $\mathrm{NDF}$ & 52.2 & 50.6 & 3.7 & NS & 52.7 & 50.0 & 3.6 & NS \\
\hline Starch & 80.5 & 81.4 & 0.8 & NS & 82.2 & 79.8 & 0.8 & NS \\
\hline
\end{tabular}

${ }^{1} \mathrm{GC}=$ ground corn; $\mathrm{SFC}=$ steam-flaked corn.

${ }^{2}$ Not significant $(P>0.10)$.

There was a trend $(P<0.10)$ for higher molar proportions of butyrate with supplemental Lys than without, which is indicative of ruminal degradation of the supplemental Lys. No differences were observed in ruminal $\mathrm{pH}$, concentrations of total VFA, and molar proportions of individual VFA among GC and SFC. Ruminal $\mathrm{NH}_{3}$ concentrations were lower $(P<0.02)$ in cows fed diets supplemented with SFC compared with GC.

The decline in fiber digestion observed in our trial was not related to ruminal $\mathrm{pH}$ (Table 4), which was similar among diets. Shifts in NDF digestion from the rumen to the large intestine were observed when the particle size of corn was decreased by grinding or steamrolling (Callison et al., 2001). These authors indicated that the shift in site of NDF digestion was related to increased starch availability. Steam-flaking grain increases both ruminal and intestinal starch digestibility compared with dry-rolled grain (Theurer et al., 1999). Although there was a trend for increased reticulo-ruminal starch digestibility in our trial, differences among treatments were less than those reported by Theurer et al. (1999). In contrast to our results, Santos et al. (1999) reported increased whole tract digestibility of DM, OM, CP, and starch for diets supplemented with SFC compared with steam-rolled corn. The DMI (3.3\% of BW) in the current trial was lower than that normally observed for lactating Jerseys (Bernard, 1999; Bernard et al., 1999) and would presumably reduce passage

Table 4. Concentrations of metabolites in ruminal fluid of lactating Jersey cows fed diets containing supplemental lysine and processed corn.

\begin{tabular}{|c|c|c|c|c|c|c|c|c|}
\hline & \multicolumn{3}{|c|}{ Lysine supplementation } & \multirow[b]{2}{*}{$\mathrm{P}$} & \multicolumn{3}{|c|}{ Corn processing } & \multirow[b]{2}{*}{$\mathrm{P}$} \\
\hline & 0 & + & $\mathrm{SE}$ & & $\mathrm{GC}^{1}$ & SFC & SE & \\
\hline $\mathrm{pH}$ & 6.35 & 6.35 & 0.05 & $\mathrm{NS}^{2}$ & 6.39 & 6.31 & 0.05 & NS \\
\hline $\mathrm{NH}_{3}, \mathrm{mg} / \mathrm{dl}$ & 14.40 & 13.00 & 0.63 & NS & 15.02 & 12.37 & 0.64 & 0.02 \\
\hline Total VFA, mM & 62.90 & $\begin{array}{r}47.87 \\
-\%\end{array}$ & 6.65 & NS & $\begin{array}{r}53.79 \\
-\%\end{array}$ & 56.97 & 6.74 & NS \\
\hline Acetate & 61.58 & 58.60 & 1.30 & NS & 61.57 & 58.61 & 1.32 & NS \\
\hline Propionate & 22.31 & 22.88 & 0.72 & NS & 21.87 & 23.31 & 0.73 & $\mathrm{NS}$ \\
\hline Butyrate & 10.73 & 12.19 & 0.54 & 0.10 & 10.79 & 12.13 & 0.55 & $\mathrm{NS}$ \\
\hline Isobutyrate & 1.67 & 1.97 & 0.27 & NS & 1.78 & 1.85 & 0.28 & NS \\
\hline Isovalerate & 2.00 & 2.19 & 0.24 & NS & 2.08 & 2.11 & 0.24 & $\mathrm{NS}$ \\
\hline Valerate & 1.71 & 2.18 & 0.19 & NS & 1.90 & 1.99 & 0.19 & NS \\
\hline
\end{tabular}

${ }^{1} \mathrm{GC}=$ ground corn; $\mathrm{SFC}=$ steam-flaked corn.

${ }^{2}$ Not significant $(P>0.10)$. 
Table 5. Intake, flow, and digestibility of $\mathrm{N}$ for lactating cows consuming diets containing supplemental lysine and processed corn.

\begin{tabular}{|c|c|c|c|c|c|c|c|c|}
\hline & \multicolumn{3}{|c|}{ Lysine supplementation } & \multirow[b]{2}{*}{$\mathrm{P}$} & \multicolumn{3}{|c|}{ Corn processing } & \multirow[b]{2}{*}{$\mathrm{P}$} \\
\hline & 0 & + & SE & & $\mathrm{GC}^{1}$ & SFC & SE & \\
\hline Intake, $\mathrm{g} / \mathrm{d}$ & 385.8 & 391.4 & 7.2 & $\mathrm{NS}^{2}$ & 376.7 & 400.4 & 7.0 & 0.07 \\
\hline $\begin{array}{l}\text { Duodenal flow, g/d } \\
\text { Total }\end{array}$ & 264.1 & 238.1 & 16.8 & NS & 210.5 & 291.6 & 16.3 & 0.02 \\
\hline Bacterial & 194.5 & 205.5 & 26.1 & NS & 157.8 & 242.1 & 25.4 & 0.07 \\
\hline Reticulo-rumen apparent digestibility, $\%$ & 34.6 & 39.1 & 2.2 & NS & 42.2 & 31.5 & 2.2 & 0.02 \\
\hline $\begin{array}{l}\text { Bacterial protein synthesis efficiency } \\
\text { g CP/100 g OM apparently digested } \\
\text { g CP/100 g OM truly digested }\end{array}$ & $\begin{array}{l}27.4 \\
23.3\end{array}$ & $\begin{array}{l}27.7 \\
23.6\end{array}$ & $\begin{array}{l}2.7 \\
2.3\end{array}$ & $\begin{array}{l}\text { NS } \\
\text { NS }\end{array}$ & $\begin{array}{l}21.7 \\
18.1\end{array}$ & $\begin{array}{l}33.4 \\
28.8\end{array}$ & $\begin{array}{l}2.7 \\
2.3\end{array}$ & $\begin{array}{l}0.03 \\
0.02\end{array}$ \\
\hline Whole tract apparent digestibility, \% & 73.9 & 74.8 & 1.1 & NS & 74.9 & 73.7 & 1.1 & NS \\
\hline
\end{tabular}

${ }^{1} \mathrm{GC}=$ ground corn; $\mathrm{SFC}$ = steam-flaked corn.

${ }^{2}$ Not significant $(P>0.10)$.

rates through the digestive tract, allowing more time for digestion in the reticulo-rumen and reduce any potential differences due to processing.

In contrast to our results, Joy et al. (1997) observed decreased molar proportions of acetate and increased molar proportion of propionate with SFC compared with dry-rolled corn. These researchers did not observe any change in ruminal $\mathrm{pH}$ or $\mathrm{NH}_{3}$. When $\mathrm{SFC}$ was compared with dry-rolled and high moisture corn in feed lot diets, ruminal $\mathrm{pH}, \mathrm{NH}_{3}$ concentrations, and molar proportions of acetate were lowest and total VFA concentrations and molar proportions of propionate were highest with SFC (Cooper et al., 2002). The reason for the lack of change in molar proportions of VFA in the current trial with SFC is not clear. As stated earlier, differences in reticulo-rumen starch digestibility were not as great as those reported by Theurer et al. (1999). The shift in NDF digestion from the rumen to the large intestine and reduction in ruminal $\mathrm{NH}_{3}$ concentrations are consistent with greater starch digestion in the rumen which would normally be expected to reduce acetate and increase propionate.

Intake and flow of $\mathrm{N}$ to the duodenum were similar for diets with and without supplemental Lys (Table 5). Apparent digestibility of $\mathrm{N}$ in the reticulo-rumen and whole tract was not affected by supplemental Lys. Intake of $\mathrm{N}$ tended to be higher $(P<0.07)$ and flow of $\mathrm{N}$ to the duodenum $(P<0.02)$ was higher for diets containing SFC. Microbial $\mathrm{N}$ tended to contribute a greater $(P<$ 0.07) proportion of the total $\mathrm{N}$ flow to the duodenum when diets were supplemented with SFC. Efficiency of bacterial protein synthesis was greater $(P<0.03)$ for diets containing SFC based on apparent and true OM digestibility (Table 5). Total tract $\mathrm{N}$ digestibility was not affected by corn processing. The increased flow of $\mathrm{N}$ to the small intestine with SFC is consistent with studies summarized by Theurer et al. (1999). In contrast to our results, no differences were observed in flow of $\mathrm{N}$ or bacterial protein synthesis efficiency when comparing SFC to dry-rolled corn (Cooper et al., 2002; Joy et al., 1997).

Intake of Lys increased $(P<0.04)$ with supplemented Lys (Table 6) in accordance with planned treatment levels, but no differences were observed in flow of other individual AA to the duodenum among diets with and without supplemental Lys (Table 7). Intake of Met was higher $(P<0.02)$ and Arg tended to be higher $(P<0.10)$ for diets supplemented with GC, but flow of all AA to the duodenum was higher for diets supplemented with SFC.

Ruminal escape of L-lysine-HCL was reported to be $18.6 \%$ when individual AA were administered intraruminal (Velle et al., 1998) which would theoretically have provided an additional $1.86 \mathrm{~g} / \mathrm{d}$ of Lys flowing to the duodenum. However, only $5 \%$ of the supplemental Lys escaped ruminal degradation when wethers were fed diets supplemented with $6 \mathrm{~g} / \mathrm{d}$ of L-lysine-HCL (Amos and Evans, 1978). Results of this study indicate that none of the supplemental Lys escaped ruminal degradation based on duodenal concentrations. However, Harrison et al. (2000) reported a positive effect on milk yield in response to supplemental Met and Lys. These authors suggested that the response was possibly due to an increase in microbial protein synthesis based on increased concentrations of allantoin in milk (Harrison, personal communication). However, supplemental Lys did not affect microbial protein synthesis in our trial.

Results of this study are consistent with previous research in which SFC improved microbial protein synthesis and $\mathrm{N}$ flow to the small intestine (Theurer et al, 1999). In contrast to our results, Joy et al. (1997) did not observe an differences in the flow of AA to the duodenum of cows fed dry rolled corn or SFC.

\section{CONCLUSIONS}

Supplemental L-lysine-HCL was not effective in stimulating microbial protein synthesis or increasing the 
Table 6. Amino acid intake of lactating Jersey cows fed diets containing supplemental lysine and processed corn.



${ }^{1} \mathrm{GC}=$ ground corn; SFC $=$ steam-flaked corn.

${ }^{2}$ Not significant $(P>0.10)$.

flow of AA to the duodenum. Intake of the cows in this experiment averaged only $3.3 \%$ of BW, and that may have slowed passage rate more than previous research that suggested greater ruminal escape of L-lysine-HCL. Additional information is needed to verify the potential escape of L-lysine-HCL in cows consuming larger quantities of DM that would support higher passage rates. Supplemental SFC increased flow of N and AA to the duodenum which agrees with previous research. The reasons for the lower reticulo-rumen digestibility of nu- trients with the SFC are not completely clear, but may be related to increased ruminal starch digestion. The presence of corn silage in the diet did not diminish the potential of SFC to improve microbial protein syntheses and flow to the small intestine.

\section{ACKNOWLEDGMENTS}

Partial funding and protein supplements were provided by H. J. Baker \& Bro., Inc. The authors thank

Table 7. Grams of amino acids reaching the duodenum of lactating Jersey cows fed diets containing supplemental lysine and processed corn.

\begin{tabular}{|c|c|c|c|c|c|c|c|c|}
\hline & \multicolumn{3}{|c|}{ Lysine supplementation } & \multirow[b]{2}{*}{$\mathrm{P}$} & \multicolumn{3}{|c|}{ Corn processing } & \multirow[b]{2}{*}{$\mathrm{P}$} \\
\hline & 0 & + & SE & & $\mathrm{GC}^{1}$ & SFC & $\mathrm{SE}$ & \\
\hline & & $\mathrm{g} \mathrm{AA} / \mathrm{d}$ & & & & $\mathrm{g} \mathrm{AA} / \mathrm{d}$ & & \\
\hline Met & 32.17 & 30.13 & 2.61 & $\mathrm{NS}^{2}$ & 25.58 & 36.72 & 2.54 & 0.03 \\
\hline Cys & 30.82 & 28.90 & 2.36 & NS & 25.05 & 34.67 & 2.29 & 0.04 \\
\hline Lys & 96.94 & 90.68 & 10.58 & NS & 75.67 & 111.95 & 10.28 & 0.06 \\
\hline Thr & 80.30 & 75.90 & 7.92 & NS & 63.54 & 92.65 & 7.69 & 0.05 \\
\hline Arg & 84.59 & 78.26 & 8.62 & NS & 65.98 & 96.86 & 8.37 & 0.05 \\
\hline Ile & 74.56 & 70.90 & 7.39 & NS & 58.83 & 86.63 & 7.18 & 0.05 \\
\hline Leu & 137.32 & 134.61 & 12.78 & NS & 111.07 & 160.86 & 12.41 & 0.04 \\
\hline Val & 104.42 & 97.16 & 8.91 & NS & 82.87 & 118.71 & 8.66 & 0.04 \\
\hline His & 37.47 & 36.56 & 3.34 & NS & 30.04 & 44.00 & 3.24 & 0.03 \\
\hline Phe & 80.19 & 76.27 & 6.89 & NS & 63.20 & 93.26 & 6.69 & 0.03 \\
\hline Gly & 108.58 & 95.01 & 8.98 & NS & 86.29 & 117.30 & 8.72 & 0.06 \\
\hline Ser & 80.03 & 76.12 & 7.58 & NS & 63.60 & 92.55 & 7.37 & 0.04 \\
\hline Pro & 80.75 & 79.75 & 6.15 & NS & 65.07 & 95.44 & 5.98 & 0.02 \\
\hline Ala & 100.53 & 95.24 & 9.35 & NS & 78.84 & 116.94 & 9.08 & 0.04 \\
\hline Asp & 163.85 & 152.35 & 15.35 & NS & 128.10 & 188.09 & 14.91 & 0.04 \\
\hline Glu & 210.45 & 206.99 & 21.28 & NS & 169.63 & 247.80 & 20.68 & 0.05 \\
\hline
\end{tabular}

${ }^{1} \mathrm{GC}=$ ground corn; $\mathrm{SFC}=$ steam-flaked corn.

${ }^{2}$ Not significant $(P>0.10)$. 
the dairy crew for assistance with animal care, and Melissa Tawzer and Pat Smith for their assistance in laboratory analysis.

\section{REFERENCES}

Amos, H. E., and J. J. Evans. 1978. Abomasal levels of lysine and methionine in wethers fed polymerized L-lysine-HCL and polymerized L-methionine. J. Anim. Sci. 46:778-786

Association of Official Analytical Chemists International. 1990. Official Methods of Analysis. Vol. I. 15th ed. AOAC, Arlington, VA.

Association of Official Analytical Chemists International. 2002. Official Methods of Analysis. Vol. I. 17th ed. AOAC, Arlington, VA.

Bernard, J. K. 1999. Performance of lactating dairy cows fed whole cottonseed coated with gelatinized corn starch. J. Dairy Sci. 82:1305-1309.

Bernard, J. K., M. C. Calhoun, and S. A. Martin. 1999. Effect of coating whole cottonseed on performance of lactating dairy cows. J. Dairy Sci. 82:1296-1304.

Brisson, G. L. 1956. On routine determination of chromic oxide in feces. Can. J. Agric. Sci. 36:210-212.

Callison, S. L., J. L. Firkins, M. L. Eastridge, and B. L. Hull. 2001. Site of nutrient digestion by dairy cows fed corn of different particle sizes or steam-rolled. J. Dairy Sci. 84:1458-1467.

Cooper, R. J., C. T. Milton, T. J. Klopfenstein, T. L. Scott, C. B. Wilson, and R. A. Mass. 2002. Effect of corn processing on starch digestion and bacterial crude protein flow in finishing cattle. J. Anim. Sci. 80:797-804.

Hall, M. B., 2001. Neutral detergent-soluble carbohydrates nutritional relevance and analysis. Bull. 339. Univ. Florida, Inst. Food Agric. Sci., Gainesville.

Harrison, J. H., D. Davidson, L. Johnson, M. L. Swift, M. VonKeyserlingk, M. Vazquez-Anaon, and W. Chalupa. 2000. Effect of source of bypass protein and supplemental Alimet and lysine-HCL on lactation performance. J. Dairy Sci. 83(Suppl. 1):268. (Abstr.)

Hoover, W. H., and S. R. Stokes. 1991. Balancing carbohydrates and protein for optimum rumen microbial yield. J. Dairy Sci. 74:3630-3644.
Joy, M. T., E. J. DePeters, J. G. Fadel, and R. A. Zinn. 1997. Effects of corn processing on the site and extent of digestion in lactating cows. J. Dairy Sci. 80:2087-2097.

National Research Council. 1989. Nutrient Requirements of Dairy Cattle 5th rev. ed. Natl. Acad. Sci., Washington, DC.

National Research Council. 2001. Nutrient Requirements of Dairy Cattle 6th rev. ed. Natl. Acad. Sci., Washington, DC.

O'Connor, J. D., C. J. Sniffen, D. G. Fox, and W. Chalupa. 1993. A net carbohydrate and protein system for evaluating cattle diets: IV. Predicting amino acid adequacy. J. Anim. Sci. 71:1298-1311.

Santos, J. E. P., J. T. Huber, C. B. Theurer, L. G. Nussio, M. Tarazon, and F. A. P. Santos. 1999. Response of lactating dairy cows to steam-flaked sorghum, steam-flaked corn, or steam-rolled corn and protein sources of differing degradability. J. Dairy Sci. 82:728-737.

SAS User's Guide: Statistics, Version 6 Edition. 1989. SAS Inst., Inc. Cary, NC.

Schwab, C. G., C. K. Bozak, N. L. Whitehouse, and M. M. A. Mesbah. 1992a. Amino acid limitation and flow to the duodenum at four stages of lactation. 1. Sequence of lysine and methionine limitation. J. Dairy Sci. 75:3486-3502.

Schwab, C. G., C. K. Bozak, N. L. Whitehouse, and V. M. Olson. 1992b. Amino acid limitation and flow to the duodenum at four stages of lactation. 2. Extent of lysine limitation. J. Dairy Sci. 75:3503-3518.

Supelco Bull. 7498. 1975. GC separation of VFA C2-C25. Supelco, Bellfonte, PA.

Theurer, C. B., J. T. Huber, A. Delgado-Elorduy, and R. Wanderley. 1999. Invited review: Summary of steam-flaking corn or sorghum grain for lactating dairy cows. J. Dairy Sci. 82:1950-1959.

Van Soest, P. J., J. B. Robertson, and B. A. Lewis. 1991. Methods for dietary fiber, neutral detergent fiber, nonstarch polysaccharides in relation to animal production. J. Dairy Sci. 74:3583-3597.

Velle, W., T. I. Kanui, A. Aulie, and Ø. V. Sjaastad. 1998. Ruminal escape and apparent degradation of amino acids administered intraruminally in mixtures to cows. J. Dairy Sci. 81:3231-3238.

Zinn, R. A., and F. N. Owens. 1986. A rapid procedure for purine measurement and its use for estimating net ruminal protein synthesis. Can. J. Anim. Sci. 66:157-166. 